\title{
A review of extracorporeal membrane oxygenation in child after cardiac surgery: analyses of outcomes
}

\author{
M Asano*, Y Nakai, H Matsumae, T Ukai, N Nomura, A Mishima \\ From 23rd World Congress of the World Society of Cardio-Thoracic Surgeons \\ Split, Croatia. 12-15 September 2013
}

\section{Background}

The use of extracorporeal membrane oxygenation (ECMO) after cardiac surgery in child has continued to increase. However, the survivals have remained less than $50 \%$ with a significant rate of complications. We aim to assess the morbidity and mortality in children requiring ECMO after cardiotomy and determine factors affecting outcomes.

\section{Methods}

Sixty-two ECMO operations in 58 children who required post-cardiotomy ECMO between January 2002 and December 2012 were reviewed. The Cox proportional hazards model was used for the univariate and multivariate prognostic risk analyses for the weaning of ECMO or the discharge of hospital.

\section{Results}

Age and weight were $12 \pm 17$ months and $6.4 \pm 3.3 \mathrm{~kg}$, respectively. Twenty patients had single ventricle and 38 had biventricular physiology. The duration of ECMO was $8.4 \pm 4.4$ days. Fifty-two $(84 \%)$ were successfully weaned off ECMO and 34 (55\%) survived to hospital discharge. The weaning from ECMO was affected by peak serum lactate during ECMO (risk ratio $=1.02$, 95\% CI: $1.003-1.036, \mathrm{p}=0.0181)$ and the diagnosis of isomerism $(46,0.0004-0.41,0.0085)$ by multivariate analysis. Indication for ECMO and surgical procedures were not significant predictors. Factors associate with failure of hospital discharge despite successful decannulation were as follows: weight $(0.32,0.14-0.62,0.0001)$, ECMO duration $(1.3,1.02-1.72,0.0352)$, the duration of the day

\footnotetext{
* Correspondence: cvsasano@med.nagoya-cu.ac.jp

Cardiovascular Surgery, Nagoya City University, Nagoya, Japan
}

between decannulation and the first day of negative water balance after ECMO (1.3, 1.13-1.54, 0.0001), the use of nitric oxide gas after ECMO (8.4, 1.81-46.66, 0.0068 ). Survivor vs. non-survivor to the hospital discharge was $7.1 \pm 4.1$ vs. $10.0 \pm 4.2$ (days) in ECMO duration $(\mathrm{p}=0.0073)$ and $2.1 \pm 1.5$ vs. $8.3 \pm 10.2$ (days) in the negative water balance $(\mathrm{p}=0.0004)$.

\section{Conclusions}

Higher lactate levels and isomerism are significant factors associated with mortality during ECMO. Unable to obtain earlier negative balance and the inhalation of nitric oxide increase risk of death after successful decannulation.

Published: 11 September 2013

doi:10.1186/1749-8090-8-S1-080

Cite this article as: Asano et al:: A review of extracorporeal membrane oxygenation in child after cardiac surgery: analyses of outcomes. Journal of Cardiothoracic Surgery 2013 8(Suppl 1):080.

Submit your next manuscript to BioMed Central and take full advantage of:

- Convenient online submission

- Thorough peer review

- No space constraints or color figure charges

- Immediate publication on acceptance

- Inclusion in PubMed, CAS, Scopus and Google Scholar

- Research which is freely available for redistribution 